\title{
PALAEOMAGNETIC AND U-SERIES DATING OF CAVE SEDIMENTS IN BARADLA CAVE, HUNGARY
}

\section{DATACIJE JAMSKIH SEDIMENTOV S PALEOMAGNETNO IN URAN TORIJEVO METODO V JAMI BARADLA NA MADŽARSKEM}

PAVEL BOSÁK ${ }^{1} \&$ HELENA HERCMAN ${ }^{2} \&$ JAROSLAV KADLEC $^{1} \&$ JÁNOS MÓGA ${ }^{3} \&$ PETR PRUNER ${ }^{1}$

\footnotetext{
${ }^{1}$ Institute of Geology, Academy of Sciences of the Czech Republic, Rozvojová 135, 16502 Praha 6, Czech Republic,inst@gli.cas.cz

${ }^{2}$ Institute of Geological Sciences, Polish Academy of Sciences, ul. Twarda 51/55, 00-818 Warszawa, Poland, hhercman@twarda.pan.pl

${ }^{3}$ Eötvös Loránd University, TTK Geography Department, Pázmány P. sétány 1/c, 1117 Budapest, Hungary, jmoga@freemail.hu
} 


\section{Abstract \\ UDC: 550.38:552.54(439) \\ Pavel Bosák \& Helena Hercman \& Jaroslav Kadlec \& János Móga \& Petr Pruner: Palaeomagnetic and U-series dating of cave sediments in Baradla Cave, Hungary}

Fine-grained siliciclastic sediments from the main gallery and upper cave level show nearly uniform composition and sedimentary textures. Palaeomagnetic analysis indicates normal magnetic polarisation of all samples, i.e. the age younger than Brunhes/Matuyama boundary at $780 \mathrm{ka}$. Flowstone/stalagmite covering siliciclastics in the upper cave level contains reverse polarised samples dated by U-series method to about 114-115 ka, which can be identified as the Blake Event. The uniform composition of sediments can indicate the infill of the cave during a single event caused by the blockage of drainage routes due to geological (collapse) or palaeoclimatic (ice) changes, which took part before ca 130 to $150 \mathrm{ka}$ as indicating by the oldest $\mathrm{U}$-series data from the whole Domica-Baradla Cave System.

Key words: cave sediments, palaeomagnetic dating, U/Th dating, Baradla Cave, Hungary.

\section{Izvleček}

UDK: 550.38:552.54(439)

\section{Pavel Bosák \& Helena Hercman \& Jaroslav Kadlec \& János Móga \& Petr Pruner: Datacije jamskih sedimentov s paleomagnetno in uran torijevo metodo $v$ jami Baradla na Madžarskem}

Drobnozrnati siliklastični sedimenti glavne galerije in gornjega nivoja jame Baradla, izkazujejo veliko homogenost v zgradbi in sedimentnih teksturah. Paleomagnetne analize kažejo normalno polarizacijo vseh vzorcev, kar pomeni starost, ki je mlajša od meje Brunhes/Matuyama pri 780 ka. Siga oz. stalagmiti, ki pokrivajo siliklaste v gornjem jamskem nivoju, vsebujejo tudi reverzno polarizirane vzorce, katerih datacije $\mathrm{z}$ uran torijevo metodo kažejo na starost 114-115 ka, kar nakazuje na dogodek Blake. Homogenost sedimentov lahko razložimo z enkratnim dogodkom, kjer je zapolnitev s sedimentom povzročil zastoj pretoka. Temu so lahko botrovali geološki (npr. podor) ali paleoklimatski vzroki pred približno 130-150 ka, kolikor je tudi najvišja starost sedientov v sistemu Domica-Baradla izmerjena z metodo uran-torij.

Ključne bedsede: jamski sedimenti, paleomagnetno datiranje, datiranje z metodo U/Th, jama Baradla, Madžarska. 


\section{INTRODUCTION}

The Baradla Cave is located in NE Hungary in the Aggtelek Karst. The cave represents a part of extensive cave system Domica-Baradla crossing the Slovak/Hungarian border from ponors in the Slovak Karst (Silica Plateau) to resurgences in the Aggtelek Karst. The area represents the part of the World Heritage Site of UNESCO. The total length of the system is about $25 \mathrm{~km}$, of which $5.4 \mathrm{~km}$ is on the Slovak territory.

The area is built mostly of Mesozoic (dominantly Triassic) carbonate rocks belonging to the Silica Nappe of the Silicicum tectonic unit (cf. e.g., Mello et al., 1997; Plašienka, 1999). Carbonates are unconformably overlain by siliciclastics of the Poltár Formation (late Miocene - Pontian), which are interpreted as deposits of alluvial plain fed from erosion of uplifting mountain ranges in the Slovak territory (Mello et al., 1997). They encircle limestone outcrops from the west and southwest. The Cainozoic geomorphological evolution was described in detail by Móga (1999). Cave evolution was summarised e.g., by Jakucs (1956), Sásdi (1990), Bella (2000) or Zámbó et al. (2002).

The field work started in August 2001 by checking the whole accessible part of the Baradla Cave and site pre-selection (P. Bosák, J. Kadlec). During November 2001, samplig on profiles was carried out (J. Móga from the Geography Department of the ELFI, Budapest, Hungary, P. Bosák, P. Pruner, J. Kadlec, M. Chadima, L. Maggini from the Institute of Geology AS CR, Praha, Czech Republic, and S. Leél-Ôssy from the Geology Department of the ELFI, Budapest, Hungary).

In all 5 profiles of unconsolidated sediments were selected for sampling. Four profiles resulted from site pre-selection and one profile was sampled at the request of S. Leél-Őssy. Profiles were situated regularly in the plan of the cave and in different altitudes as follows (Fig. 1): Arany-utca (sample symbol BCA); Meseország (BCB); Nádor utcája (BCC); Rákosi-ág (BCD), and Münnichtáró (BCE). One profile was located in the main branch of the cave (Nádor utca) and two in the upper cave level (Münnich-táró, Meseország). Profiles in Rákosi-ág and Arany-utca were situated in narrower side branches (invasion vadose passages from the south and east, i.e. from the landscape on siliciclastics of the Poltár Formation). In total 96 samples were taken ( 88 samples of unconsolidated sediments and 8 samples of speleothems; Tab. 1).

The aim of the research was to detect palaeomagnetic and magnetostratigraphic properties of the cave fill and to compare them with similar data from Domica Cave (Slovakia; Pruner et al., 2000)

\begin{tabular}{|l|c|c|c|}
\hline Site & Abbreviation & Number of samples & $\begin{array}{c}\text { Type of } \\
\text { demagnetisation }\end{array}$ \\
\hline Arany-utca & \multirow{2}{*}{ BCA } & 21 & AC \\
& BCB & 13 & TD \\
\hline Meseország & \multirow{2}{*}{ BCC } & 1 & AC \\
\hline \multirow{2}{*}{ Nádor utcája } & \multirow{2}{*}{ BCD } & 3 & TD \\
\hline Rákosi-ág & \multirow{2}{*}{ BCE } & 4 & TD \\
\hline Münnich-táró & 2 & AC \\
& & 1 & TD \\
\hline
\end{tabular}

Table 1 List of samples

Explanations: $\mathrm{AC}$ - demagnetisation in alternating field, $\mathrm{TD}$ - thermal demagnetisation. 
and with numerical dating results from Baradla Cave (Lauritzen \& Leél-Ôssy, 1994, and L. Zámbó and D.C. Ford; L. Zámbó, pers. com., 2003; cf. Fig. 1). Results of magnetostratigraphic research in Domica Cave (Pruner et al., 2000) indicate normal magnetic polarisation of all 4 profiles (Suchá Passage and Za Klenotnicou Passage). Profiles were composed mostly of silts to clays of brown to brownish red colour, sometimes slightly sandy, with sandy gravel in one profile. Intercalations of flowstones were relatively abundant. Short inverse polarised excursion older than Blake (Jamaica, Levantine) was detected in one of profiles (Suchá Passage), which was situated under flowstone cover of profile dated to $131+10 /-9,9$ ka. Numerical dating of speloethems (U-series method) in Baradla Cave indicates similar low ages of 119 ka (Petőfi's Tomb from the Chamber of Columns; Lauritzen \& Leél-Ôssy 1994), and 100 to 150 ka (L. Zámbó and D.C. Ford, unpubl.).

\section{SITE DESCRIPTION}

\section{Arany-utca/Golden Passage (BCA)}

The site is situated in an invasion vadose passage entering from the east to the main cave corridor between Apolló Thermes and Szent Gellért Hill (Fig. 1). Natural profile (about $2 \mathrm{~m}$ in height) was situated on the left bank about $20 \mathrm{~m}$ from the junction with the main branch, behind a flowstone pillar (Fig. 2): 1 - flowstone, alternation of lighter and darker brown laminae up to $1 \mathrm{~cm}$ thick; 2 - clayey silt to silty clay, massive in the upper part, horizontally laminated in the lower part. It seems that those deposits overlay a $60-80 \mathrm{~cm}$ thick pebble layer at the passage junction. In the surroundings of the sampling site, close to the ceiling, a number of remains of flowstone crust could be traced almost at the same height as the crust at the top of the studied section. This indicates later erosion of sediments by invasion waters.

\section{Meseország/ Fairy Tale Chamber (BCB)}

Natural profile was situated in the eastern part of the Chamber belonging to the upper cave level. The whole section is covered by flowstone. Profile (about $1.2 \mathrm{~m}$ in height) was composed of (Fig. 2): 1 - flowstone, grey and white lamination, silty intercalations up to $0.3 \mathrm{~mm}$ thick; 2 - clayey silt, brown, horizontal and locally cross lamination; 3 - silty clay, reddish brown, massive, locally porous, in the upper part slightly laminated and cemented by carbonate; 4 - clayey silt, brown, horizontal lamination. Around the walls of the Chamber, flowstone crust can be noticed indicating younger exhumation of the cave fill.

\section{Nádor utcája/Nádor Street (BCC)}

Natural profile (about 1.5 in heigth), partly modified by works for opening the cave to tourists, was situated on the left bank of the riverbed, just at the concrete trail (near the Music Hall). The profile is a remnant of terrace, partly covered by flowstone and stalagmite (Fig. 2): 1 - loamy dump; 2 - sand and clayey silt, brown sandy laminae up to $0.7 \mathrm{~cm}$ thick and dark brown silty laminae up to $0.2 \mathrm{~cm}$ thick, horizontal, locally small trough bedding; 3 - flowstone, brown and rusty brown thin layers, locally grey and rusty brown lamination, calcite crystals up to $1 \mathrm{~cm} ; 4$ - sand and clayey silt, brown sandy laminae up to $0.7 \mathrm{~cm}$ thick and dark brown silty laminae up to $0.2 \mathrm{~cm}$ thick, horizontal bedding; 5 - flowstone, brown and rusty brown thin layers, locally grey and rusty brown lamination, calcite crystals up to $1 \mathrm{~cm} ; 6$ - sand and clayey silt, brown sandy laminae up to $0.7 \mathrm{~cm}$ thick and dark brown silty laminae up to $0.2 \mathrm{~cm}$ thick, horizontal, locally cross bedding; 7 - flowstone, 
brown and rusty brown thin layers, locally grey and rusty brown lamination, calcite crystals up to $1.5 \mathrm{~cm} ; 8$ - clayey silt, laminae of fine-grained brown sand up to $0.5 \mathrm{~cm}$ thick, horizontal, locally cross bedding; 9 - clay, dark brown, laminae of light brown to white grey (average thickness 0.05 $\mathrm{cm}$ ) and dark brown (thickness $0.3-0.4 \mathrm{~cm}$ ); at the base a white grey laminated flowstone crust up to $1 \mathrm{~cm}$ thick was deposited.

\section{Rákosi-ág/ Rákosi Passage (BCD)}

A small artificial excavation (about $1.3 \mathrm{~m}$ in height) was situated at the end of a short corridor on the left side of the main cave passage (Fig. 2): 1 - clayey silt to silty clay, brown, subhorizontal and locally cross lamination; 2 - flowstone, dark brown and light grey lamination, clayey intercalations and infillings of small cavities; 3 - clayey silt to silty clay, brown, subhorizontal and locally cross lamination; 4 - flowstone, honey brown, dark brown lamination, light colour in the lower part; 5 - sand, brown, medium grained, layers of clayey sandy gravel (Poltár Formation?) 5-10 cm thick, size of pebbles up to $1 \mathrm{~cm}$.

\section{Münnich-táró/ Münnich Tunnel (BCE)}

Profile (about $1.2 \mathrm{~m}$ in height) was situated in the left wall of the artificial trench in the upper cave level (Figs. 2, 3): 1 - clay, reddish brown, yellow grey silty laminae 0.05-3 mm thick locally disintegrated, reddish brown laminae $0.5-1 \mathrm{~cm}$ thick, occasionally small charcoal; 2 - flowstone,

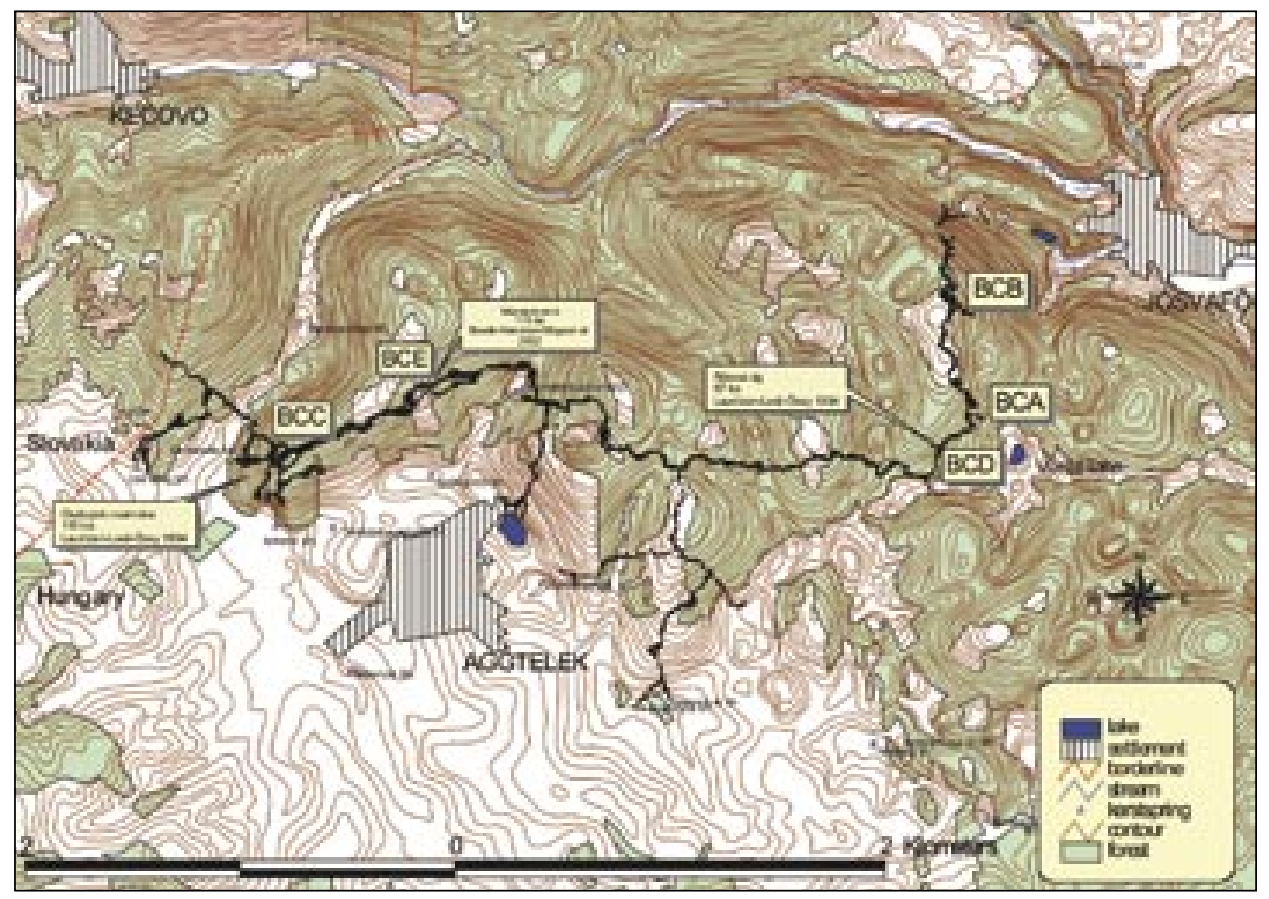

Fig. 1: Map of Baradla Cave with position of studied sites and U-series dating results. 

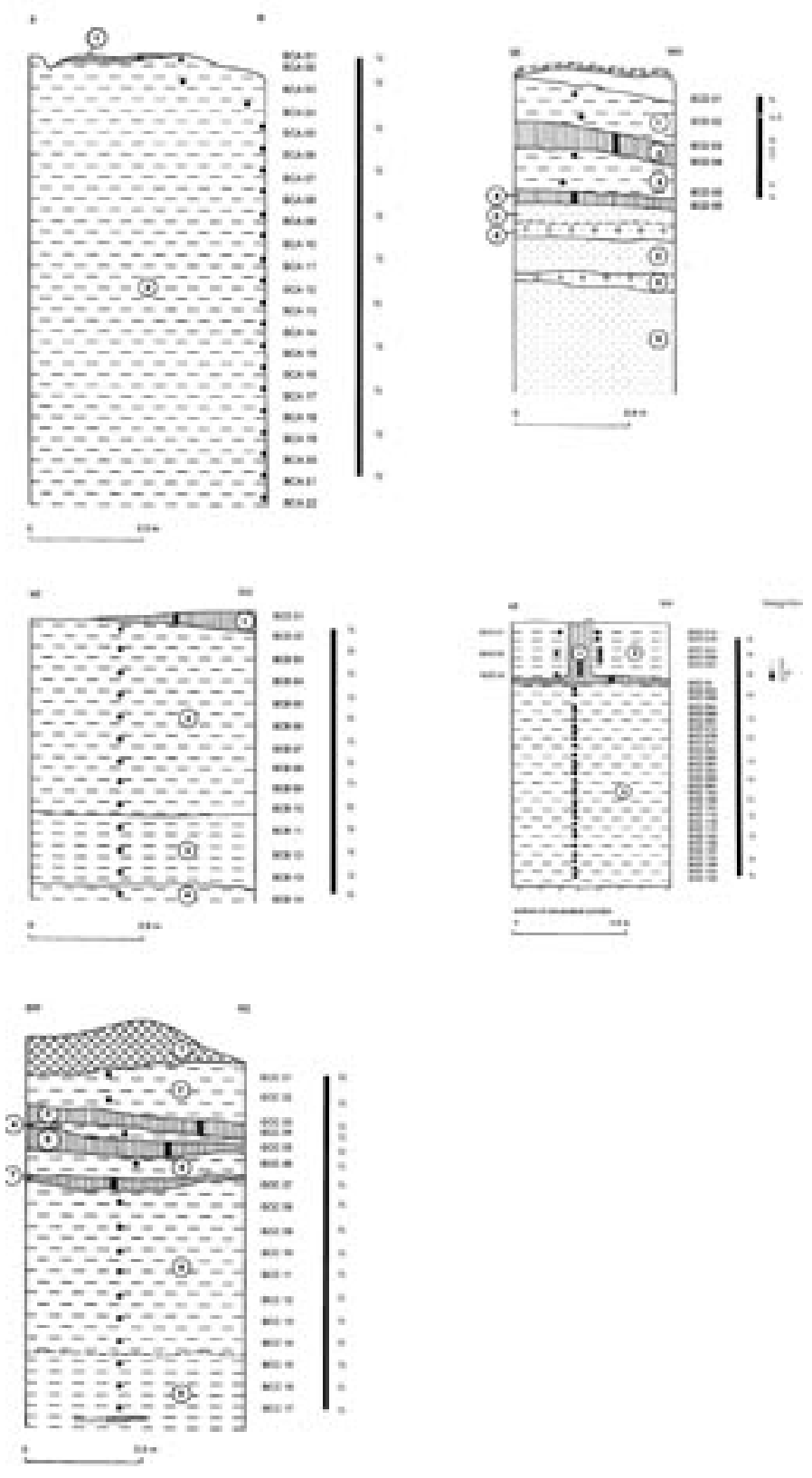

Fig. 2: Sedimentary profiles BCA to BCE with with position of paleomagnetic samples and results of paleomagnetic analysis $($ black $=$ normal $/ N ;$ white $=$ reverse $/ R)$. For description of lithology see the text. 


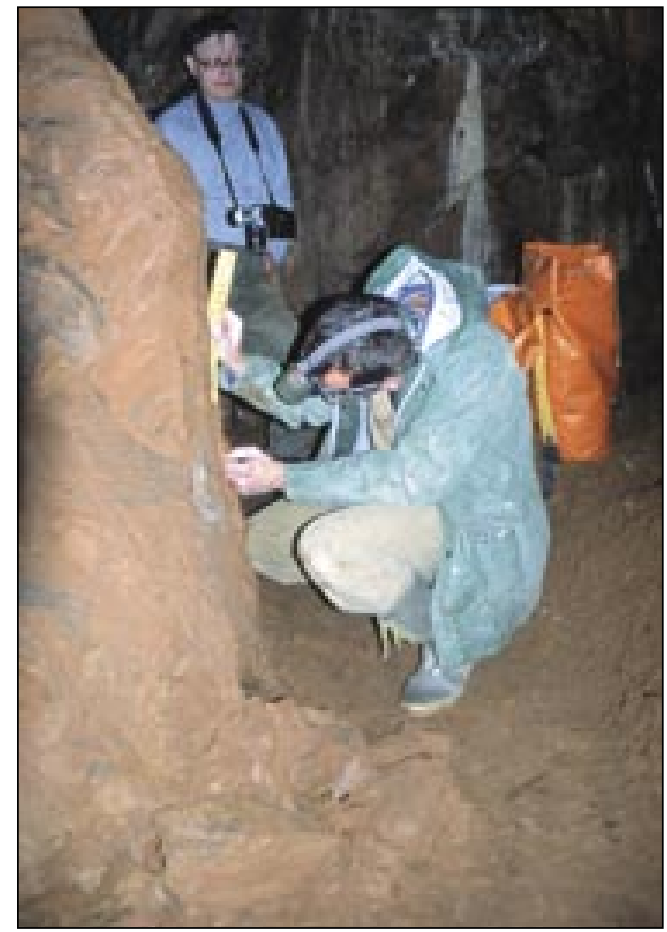

Fig. 3: Photo of profile in Münnich-táró (BCE) with speleothem crust and stalagmite (photo by J. Móga).

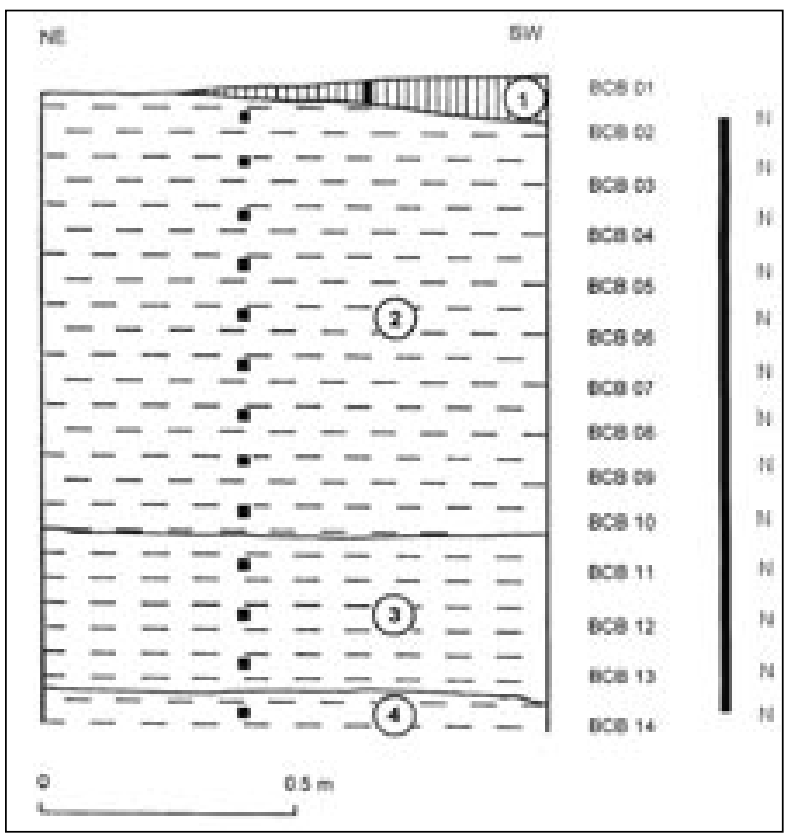

Fig. 4: Sketch of profile $B C B$ (Meseország) with the position of paleomagnetic samples and results of paleomagnetic analysis (black = normal $N$; white $=$ reverse $R$ ) Description of profile: 1 - flowstone, grey and white lamination, silty intercalations up to $0.3 \mathrm{~mm}$ thick; 2 - clayey silt, brown, horizontal and locally cross lamination; $\quad 3$-silty clay, reddish brown, massive, locally porous, in the upper part slightly laminated and cemented by carbonate; 4 - clayey silt, brown, horizontal lamination. 


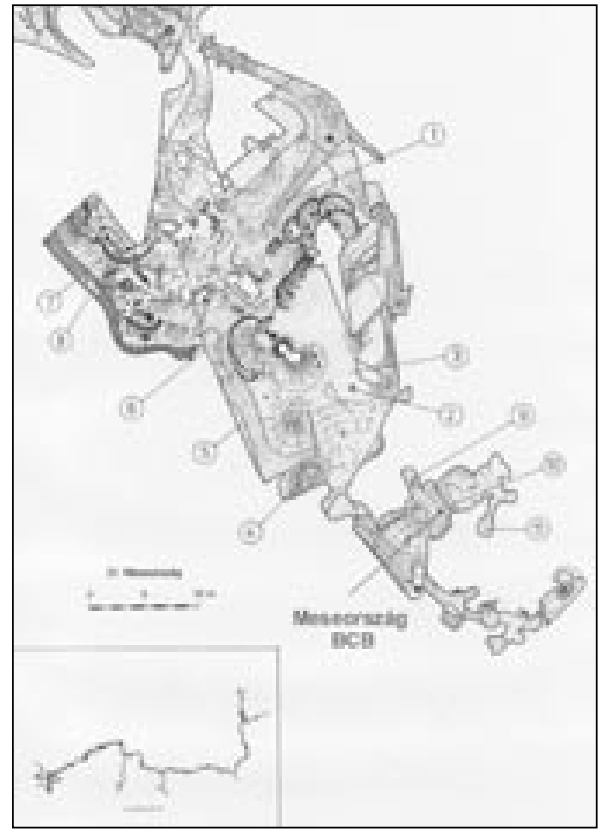

Fig. 5: Location of the BCB profile (Meseország) (map after Szunyogh G., Baradla New Atlas, with the permission of the Hungarian Cave Research of Institute).

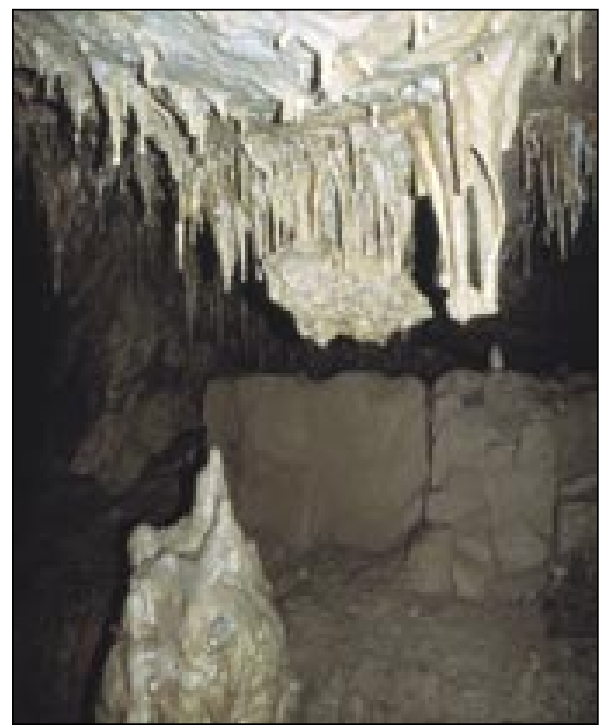

Fig. 6: Cave sediments and sinter in the Meseország (BCB). white and light laminated carbonate; 3 - clayey silt, brown, massive, locally horizontal lamination, occasionally carbonate concretions up to 7 cm thick.

\section{LABORATORY PROCEDURES}

\section{Palaeomagnetic analyses}

The laboratory procedures applied in the research of samples from the Baradla Cave are classical procedures of palaeomagnetic research of sediments and rocks. Laboratory procedures have been designed to combine the way that enabled the derivation of the respective magnetic remanence components in different temperature intervals, during progressive thermal demagnetisation (TD), and the demagnetisation by alternating field (AF), the determination of moduli and directions of remanene defined by the presence of magnetic minerals, carriers of respective remanence components, and their phase changes.

Standard sampling procedure for determination of magnetostratigraphic and rock-magnetic properties was applied using plastic cube boxes (20x20×20 mm; Japan production), which were pushed into the unconsolidated sediments in an interval of about $10 \mathrm{~cm}$. In one profile, blocks of sediments were cut from the section and later in the laboratory, cubes were pushed into them. Solid samples taken from speleothems intercalated within profiles and from flowstones covering some of them were later cut in the lab into cubes $20 \times 20 \times 20 \mathrm{~mm}$. All samples were oriented in the respect to magnetic north. Samples were measured on the spinner magnetometers JR-4 and JR-5 (Jelínek, 1966).

Laboratory specimens in their natural state were subjected to progressive TD using the MAVACS (Magnetic Vacuum Control System) apparatus securing generation of a high magnetic vacuum in medium of thermally demagnetised specimens (Př́hoda et al., 1989). All of the pecimens were also demagnetised by the alternating 


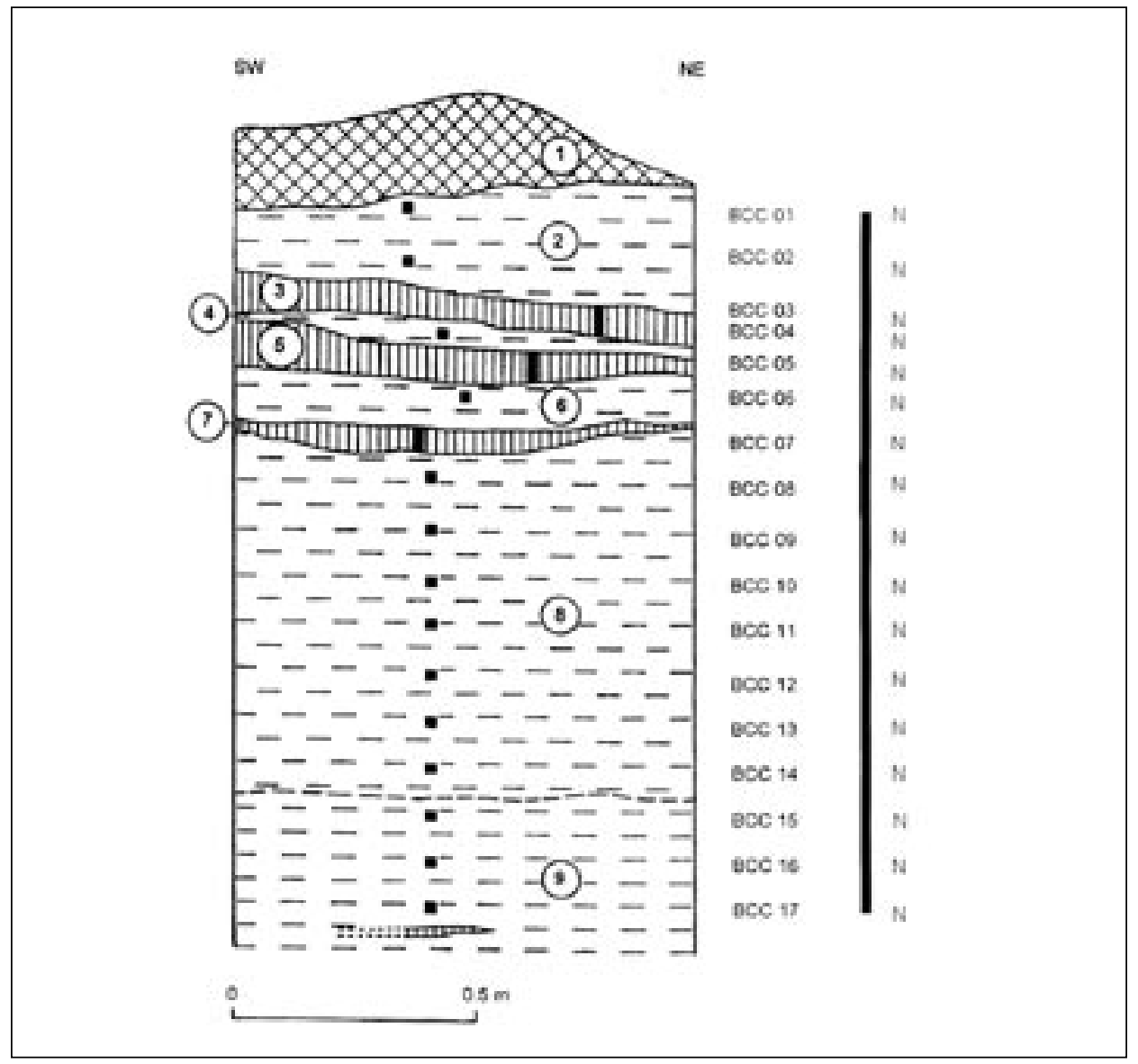

Fig. 7: Nádor utcája, Sketch of profile BCC with the position of paleomagnetic samples and results of paleomagnetic analysis (black $=$ normal $N$; white $=$ reverse $R$ ).

Description of profile:

1 - loamy dump; 2 - sand and clayey silt, brown sandy laminae up to $0.7 \mathrm{~cm}$ thick and dark brown silty laminae up to $0.2 \mathrm{~cm}$ thick, horizontal, locally small trough bedding; 3 - flowstone, brown and rusty brown thin layers, locally grey and rusty brown lamination, calcite crystals up to $1 \mathrm{~cm} ; 4$ - sand and clayey silt, brown sandy laminae up to $0.7 \mathrm{~cm}$ thick and dark brown silty laminae up to $0.2 \mathrm{~cm}$ thick, horizontal bedding; 5 - flowstone, brown and rusty brown thin layers, locally grey and rusty brown lamination, calcite crystals up to $1 \mathrm{~cm} ; 6$ - sand and clayey silt, brown sandy laminae up to $0.7 \mathrm{~cm}$ thick and dark brown silty laminae up to $0.2 \mathrm{~cm}$ thick, horizontal, locally cross bedding; 7 - flowstone, brown and rusty brown thin layers, locally grey and rusty brown lamination, calcite crystals up to $1.5 \mathrm{~cm} ; 8$ - clayey silt, laminae of fine-grained brown sand up to $0.5 \mathrm{~cm}$ thick, horizontal, locally cross bedding; 9 - clay, dark brown, laminae of light brown to white grey (average thickness $0.05 \mathrm{~cm}$ ) and dark brown (thickness 0.3-0.4 cm), at the base a white grey laminated flowstone crust up to $1 \mathrm{~cm}$ thick was deposited. 
field procedures, up to a field of 1,000 Oe (Schonstedt GSD-1).

Remanent magnetisation of specimens in their natural state (NRM) was identified by the symbol $\mathrm{J}_{\mathrm{n}}$, the corresponding remanent magnetic moment by the symbol M. Graphs of normalised values of $\mathrm{M} / \mathrm{M}_{\mathrm{o}}=\mathrm{F}(\mathrm{t})$ were constructed for each analysed specimen. Directions of $\mathrm{J}_{\mathrm{n}}$ and those of the remanent magnetisation of TD or AF demagnetised specimens in the course of progressive demagnetisation procedures were expressed in stereographic projection. The orthogonal projection of the remanent magnetisation vectors were plotted into the Zijderveld diagrams.

Phase or mineralogical changes of magnetically active (mostly Fe-oxides) minerals frequently occur during the laboratory thermal tests, especially at low temperature intervals. These changes can be derived from the graphs of normalised values of $\mathrm{k}_{\mathrm{t}} / \mathrm{k}_{\mathrm{n}}=\mathrm{f}(\mathrm{t})$, where $\mathrm{k}_{\mathrm{n}}$ designates the volume magnetic susceptibility of specimens in natural state and $\mathrm{k}_{\mathrm{t}}$ the susceptibility of specimens demagnetised at temperature ${ }^{\circ} \mathrm{C}$. The $\mathrm{k}_{\mathrm{t}}$ and $\mathrm{k}_{\mathrm{n}}$ values will be measured on a kappa-bridge KLY-2 (Jelínek, 1973).

Separation of the respective remanent magnetisation components was carried out by multi-component Kirschvink analysis (Kirschvink, 1980). The statistics of Fisher (1953) were employed for calculation of mean directions of the pertinent remanence components derived by the multi-component analysis. Palaeomagnetic analyses were carried out in the Laboratory of Paleomagnetics in Praha-Průhonice (Institute of Geology AS CR).

\section{U-series dating}

Dating of carbonates employed the ${ }^{230} \mathrm{Th} /{ }^{234} \mathrm{U}$ method. $10-15 \mathrm{~g}$ of clean, compact calcite with no visible traces of detrital admixtures have been separated from lower and upper layer of selected

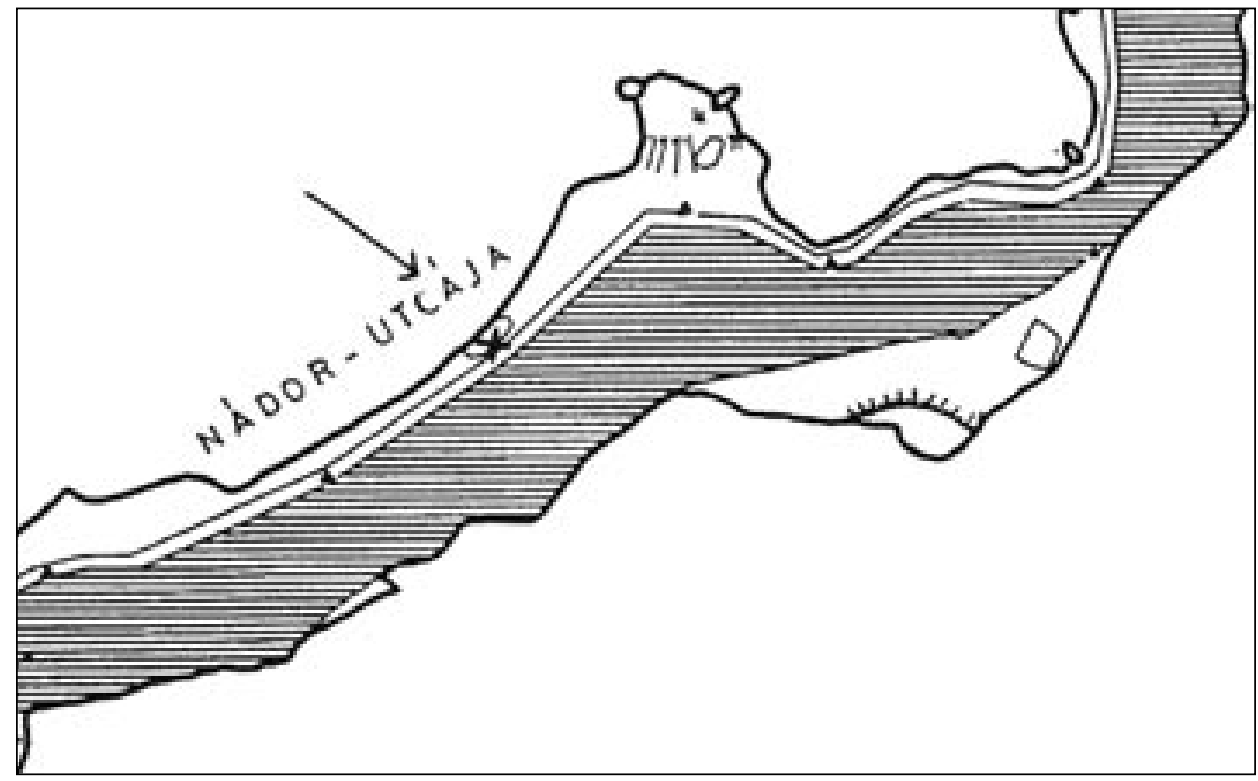

Fig. 8: Location of the profile BCC (Nádor utcája) map sheet No. 3 of the Baradla-Barlang 1: 1000, 1989). 


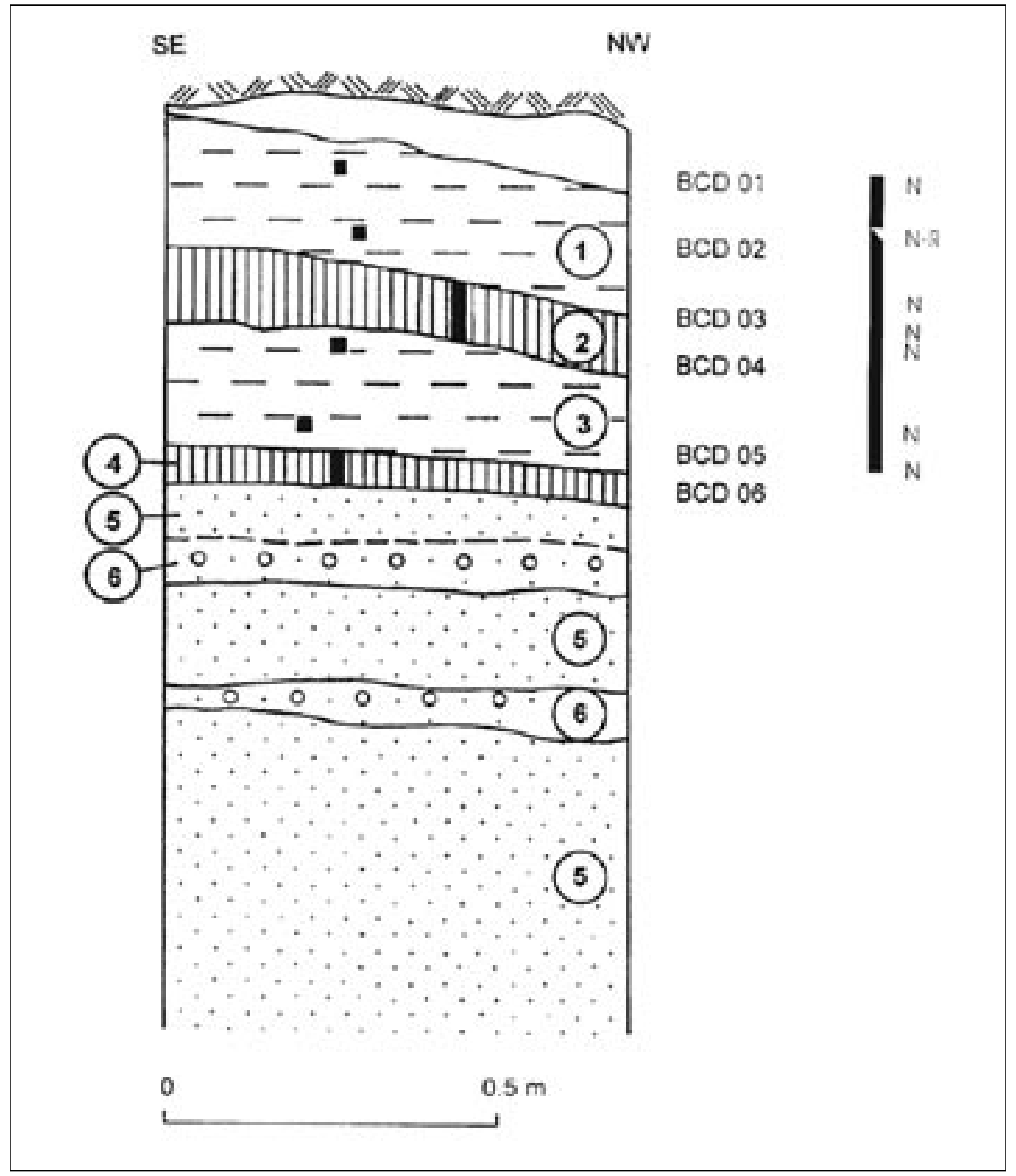

Fig. 9: Sketch of profile BCD (Rákosi-ág) with the position of paleomagnetic samples and results of paleomagnetic analysis (black $=$ normal $N$; white $=$ reverse $R)$.

Description of profile:

1 - clayey silt to silty clay, brown, subhorizontal and locally cross lamination; 2 - flowstone, dark brown and light grey lamination, clayey intercalations and infillings of small cavities; 3 - clayey silt to silty clay, brown, subhorizontal and local cross lamination; 4 - flowstone, honey brown, dark brown lamination, light colour in the lower part; 5 - sand, brown, medium grained, layers of clayey sandy gravel (the Poltár Formation) 5-10 cm thick, size of pebbles up to $1 \mathrm{~cm}$. 
part of stalagmite BCE 4. Standard chemical procedure for Uranium and Thorium separation from carbonate samples has been used (Ivanovich \& Harmon, 1992). ${ }^{228} \mathrm{Th}-{ }^{232} \mathrm{U}$ mixture has been used as a controller of chemical procedure efficiency. Uranium and Thorium have been separated by ion exchange using DOWEX 1x8 resin. After final purification, $U$ and Th have been electro-deposited on steel disks. Energetic spectra of alpha particles have been collected using OCTETE PC spectrometer made by EG\&G ORTEC. Spectra analyses and age calculations were done using "URANOTHOR 2.6" software, which is standard software developed in U-Series Laboratory in Warsaw (Gorka \& Hercman, 2002). The quoted errors are $1 \sigma$. U-series analyses were carried out in U-Series Laboratory of the Institute of Geological Sciences PAS in Warszawa, Poland.

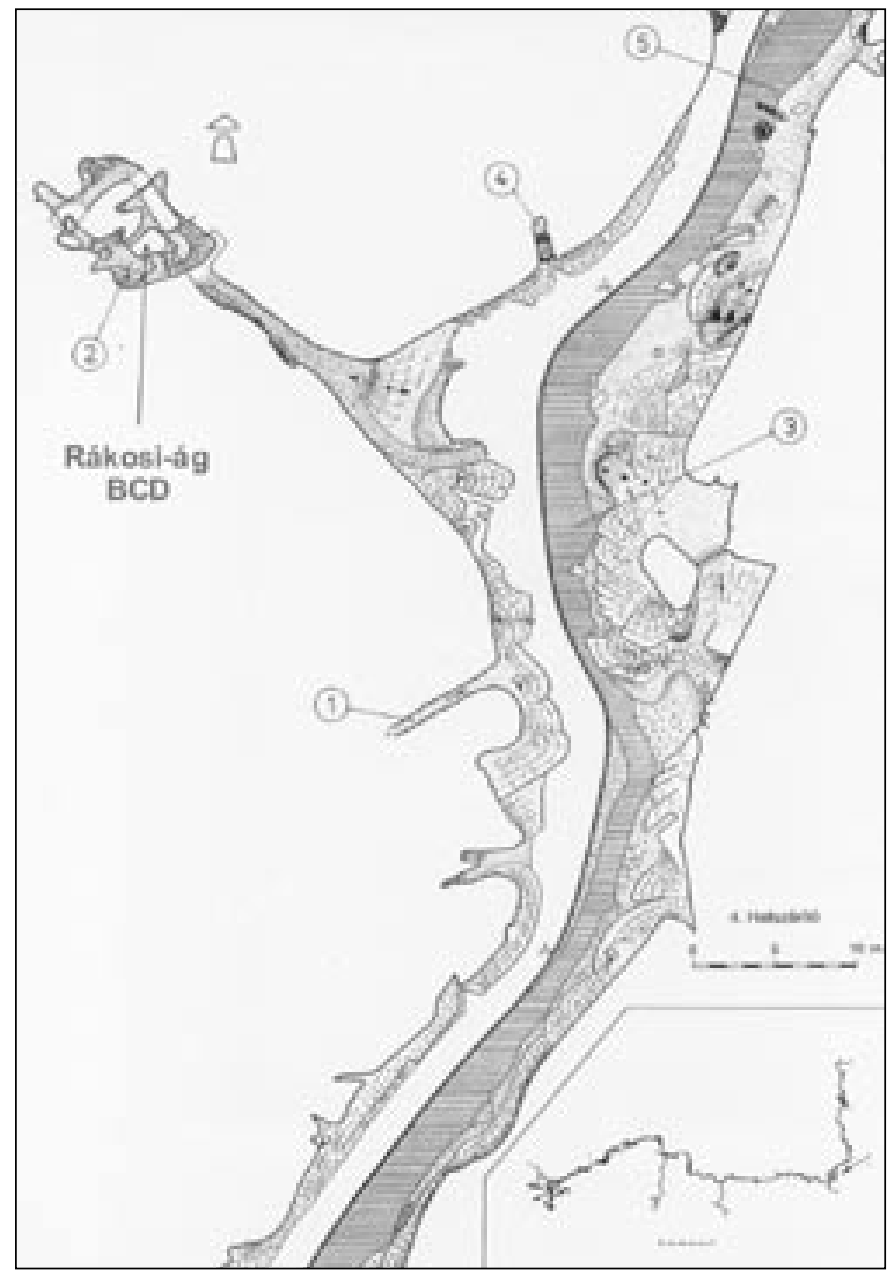

Fig. 10: Position of the BCD profile (Rákosi-ág) (map after Szunyogh G., Baradla New Atlas, with the permission of the Hungarian Cave Research Institute).

\section{RESULTS}

\section{Palaeomagnetismand magnetostratigraphy}

Principal petromagnetic and palaeomagnetic parameters are documented in Table 2 for all five profiles. Values of the moduli of natural remanent magnetisation $\mathrm{J}_{\mathrm{n}}$ and those of magnetic susceptibility $\mathrm{k}_{\mathrm{n}}$ of the studied rocks in their natural state show small scatter. The natural remanent magnetisation $\mathrm{J}_{\mathrm{n}}$ from samples of the profile $\mathrm{BCA}$ range from 0.12 to $0.48[\mathrm{~mA} / \mathrm{m}]$. The mean values of magnetic susceptibility $\mathrm{k}_{\mathrm{n}}$ from samples of the profile BCA are $\mathrm{k}_{\mathrm{n}}=526 \pm 285 \times 10^{-6}[\mathrm{SI}]$. The natural remanent magnetisation $\mathrm{J}_{\mathrm{n}}$ from samples of the profile $\mathrm{BCB}$ range from 0.25 to $0.66[\mathrm{~mA} /$ $\mathrm{m}]$. The mean values of magnetic susceptibility $\mathrm{k}_{\mathrm{n}}$ from samples of the profile $\mathrm{BCB}$ are $\mathrm{k}_{\mathrm{n}}=607$ $\pm 388 \times 10^{-6}[\mathrm{SI}]$. The natural remanent magneti- 
sation $\mathrm{J}_{\mathrm{n}}$ and the mean values of magnetic susceptibility $\mathrm{k}_{\mathrm{n}}$ from samples of the profile BCC indicate bigger scatter $\mathrm{J}_{\mathrm{n}}$ is from 0.04 to $0.32[\mathrm{~mA} / \mathrm{m}]$ and $\mathrm{k}_{\mathrm{n}}=244 \times 10^{-6}[\mathrm{SI}]$ and range from 6 to $625 \mathrm{x}$ $10^{-6}\left[\mathrm{SI}\right.$. The natural remanent magnetisation $\mathrm{J}_{\mathrm{n}}$ from samples of the profile $\mathrm{BCD}$ range from 0.02 to $0.31[\mathrm{~mA} / \mathrm{m}]$. The mean values of magnetic susceptibility $\mathrm{k}_{\mathrm{n}}$ from samples of the profile BCD are $\mathrm{k}_{\mathrm{n}}=328 \times 10^{-6}[\mathrm{SI}]$ and range from -4 to $506 \times 10^{-6}[\mathrm{SI}]$. The natural remanent magnetisation $\mathrm{J}_{\mathrm{n}}$ from sediments of the profile BCE ranges from 0.02 to $0.83[\mathrm{~mA} / \mathrm{m}]$, from samples of stalagmite from 0.0008 to $0.0017[\mathrm{~mA} / \mathrm{m}]$. The mean values of magnetic susceptibility $\mathrm{k}_{\mathrm{n}}$ from soft samples of the profile $\mathrm{BCE}$ are $\mathrm{k}_{\mathrm{n}}=897 \times 10^{-6}[\mathrm{SI}]$, from samples of stalagmite range from -9 to $-11 \times 10^{-6}[\mathrm{SI}]$. This group of samples from stalagmite is characterised by very low magnetic values of $J_{n}$ and $k_{n}$.

Directions of remanent magnetisation inferred hv the ahove given nrocedures were tested using

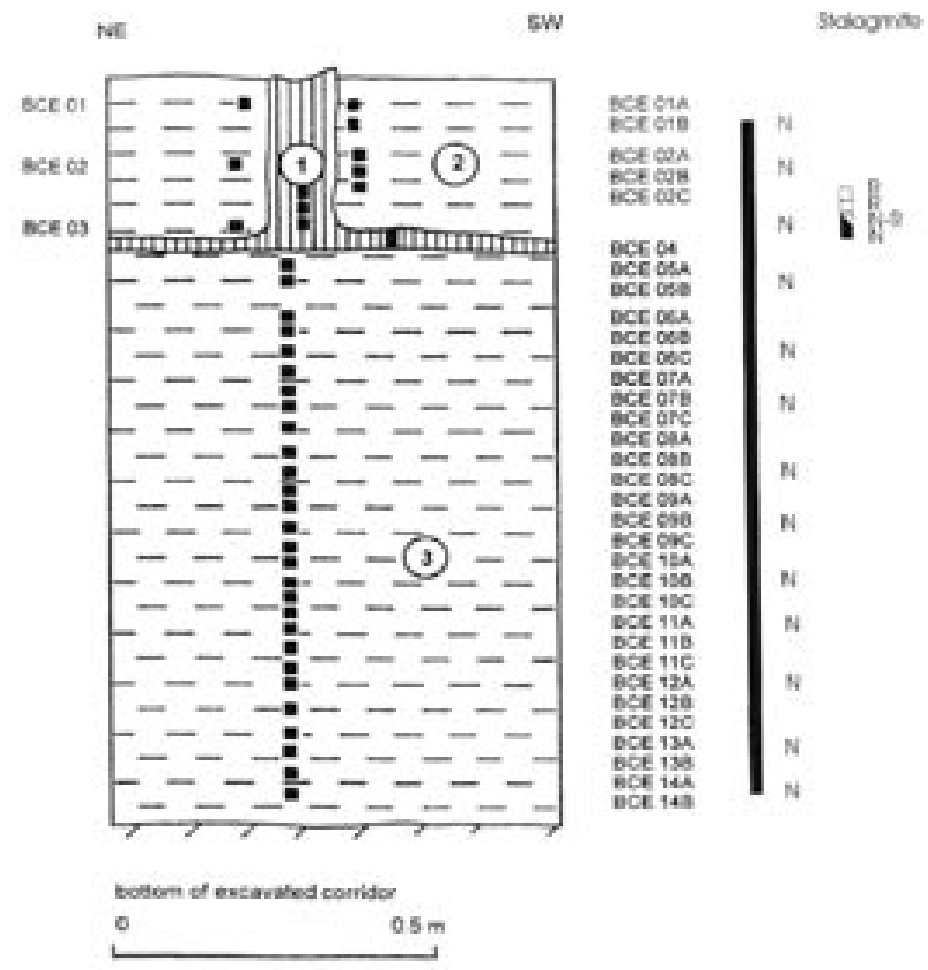

Fig. 11: Sketch of profile BCE (Münnich-táró) with the position of paleomagnetic samples and results of paleomagnetic analysis (black $=$ normal $N$; white $=$ reverse $R$ ).

Description of profile: 1 - clay, reddish brown, yellow grey silty laminae 0.05-3 mm thick locally disintegrated, reddish brown laminae 0.5-1 cm thick, occasionally small charcoal ; 2 - flowstone, white and light laminated carbonate; 3 -clayey silt, brown, massive, locally horizontal lamination, occasionally carbonate concretions up to $7 \mathrm{~cm}$ large. 
a multi-component analysis. A-components of remanence are mostly of viscous or chemoremanent (weathering) origin; they can be removed by an alternating field with the intensity of 2 up to $10 \mathrm{mT}$. Normal and reverse C-component directions $\left(\mathrm{D}_{\mathrm{p}}, \mathrm{I}_{\mathrm{p}}\right.$ - declination and inclination) of the samples are documented in Table 3. Mean palaeomagnetic direction and value of $\alpha_{95}$ (semi-vertical angle of the cone of confidence) is not possible to calculate for reverse group because it is composed only of three samples.

Palaeomagnetic and magnetostratigraphic investigations carried out on oriented laboratory specimens provided data concerning principal magnetic properties and identification of palaeomagnetic directions. Magnetostratigraphic results of samples from five profiles show normal polarity magnetozones. Speleothem (stalagmite) samples from the BCE profile yielded deflection in declination and inclination of upper samples.

Studied samples from profiles BCA, BCB, BCC, BCD, and BCE showed only normal polarisation of all samples (unconsolidated samples demagnetised by the AF method). Speleothem (stalagmite) samples from the BCE profile yielded reverse polarisation in the lower part.

\begin{tabular}{|c|c|c|c|}
\hline & $\underset{[\mathrm{mA} / \mathrm{m}]}{\mathrm{J}_{\mathrm{n}}}$ & $\begin{array}{l}\mathrm{k}_{\mathrm{n}} \times 10^{-6} \\
{[\mathrm{SI}]}\end{array}$ & \\
\hline Mean value & 0.31 & 426 & \multirow{3}{*}{$\begin{array}{c}\text { Profile } \\
\text { BC A-BCE }\end{array}$} \\
\hline Standard deviation & 0.11 & 156 & \\
\hline $\begin{array}{l}\text { Number of } \\
\text { samples }\end{array}$ & 69 & 69 & \\
\hline Mean value & 0.0011 & -10 & \multirow[b]{3}{*}{ Speleothem BCE } \\
\hline Standard deviation & 0.0005 & -2 & \\
\hline $\begin{array}{l}\text { Number of } \\
\text { samples }\end{array}$ & 3 & 3 & \\
\hline
\end{tabular}

Table 2: Mean value and standard deviation of natural remanent magnetisation and volume magnetic susceptibility.

\begin{tabular}{|c|c|c|c|c|c|c|}
\hline \multirow{2}{*}{ Profile } & \multirow{2}{*}{ Polarity } & \multicolumn{2}{|c|}{$\begin{array}{l}\text { Mean palaeomagnetic } \\
\text { directions }\end{array}$} & \multirow{2}{*}{$\alpha_{95}$} & \multirow{2}{*}{ k } & \multirow{2}{*}{$\mathrm{n}$} \\
\hline & & $\mathrm{D}\left[{ }^{\circ}\right]$ & $\mathrm{I}\left[{ }^{\circ}\right]$ & & & \\
\hline \multirow{6}{*}{$\begin{array}{l}\text { BCA } \\
\text { BCB } \\
\text { BCC } \\
\text { BCD } \\
\text { BCE } \\
\text { BCE }\end{array}$} & $\mathrm{N}$ & 354.2 & 53.3 & 5.3 & 15.6 & 10 \\
\hline & $\mathrm{N}$ & 5.8 & 31.4 & 10.2 & 9.6 & 13 \\
\hline & $\mathrm{N}$ & 349.2 & 44.2 & 8.2 & 11.6 & 10 \\
\hline & $\mathrm{N}$ & 334.1 & 59.8 & 9.6 & 10.1 & 7 \\
\hline & $\mathrm{N}$ & 3.7 & 42.3 & 7.4 & 8.8 & 13 \\
\hline & $\mathrm{R}$ & 157.4 & 10.6 & - & - & 3 \\
\hline
\end{tabular}

Explanations: $D, I-$ declination, inclination of the remanent magnetization after dip correction, $\alpha_{95}-$ semivertical angle of the cone of confidence calculated according to Fisher (1953) at the 95\% probability level, $k$ - precission parametr, $n$ - number of analysed samples.

Table 3: Mean palaeomagnetic directions of samples 
P. Bosák \& H. Hercman \& J. Kadlec \& J. Móga \& P. Pruner: Palaeomagnetic and U-series dating of cave sediments...

\section{U-series dating}

Obtained results show sufficient uranium concentration for precise $\alpha$-spectrometry analyses. Efficiency of chemical separation of $U$ and Th were very high and as a results energetic spectra of alpha particles are clear. There were no traces of significant detrital contamination with no-radiogenic Th.

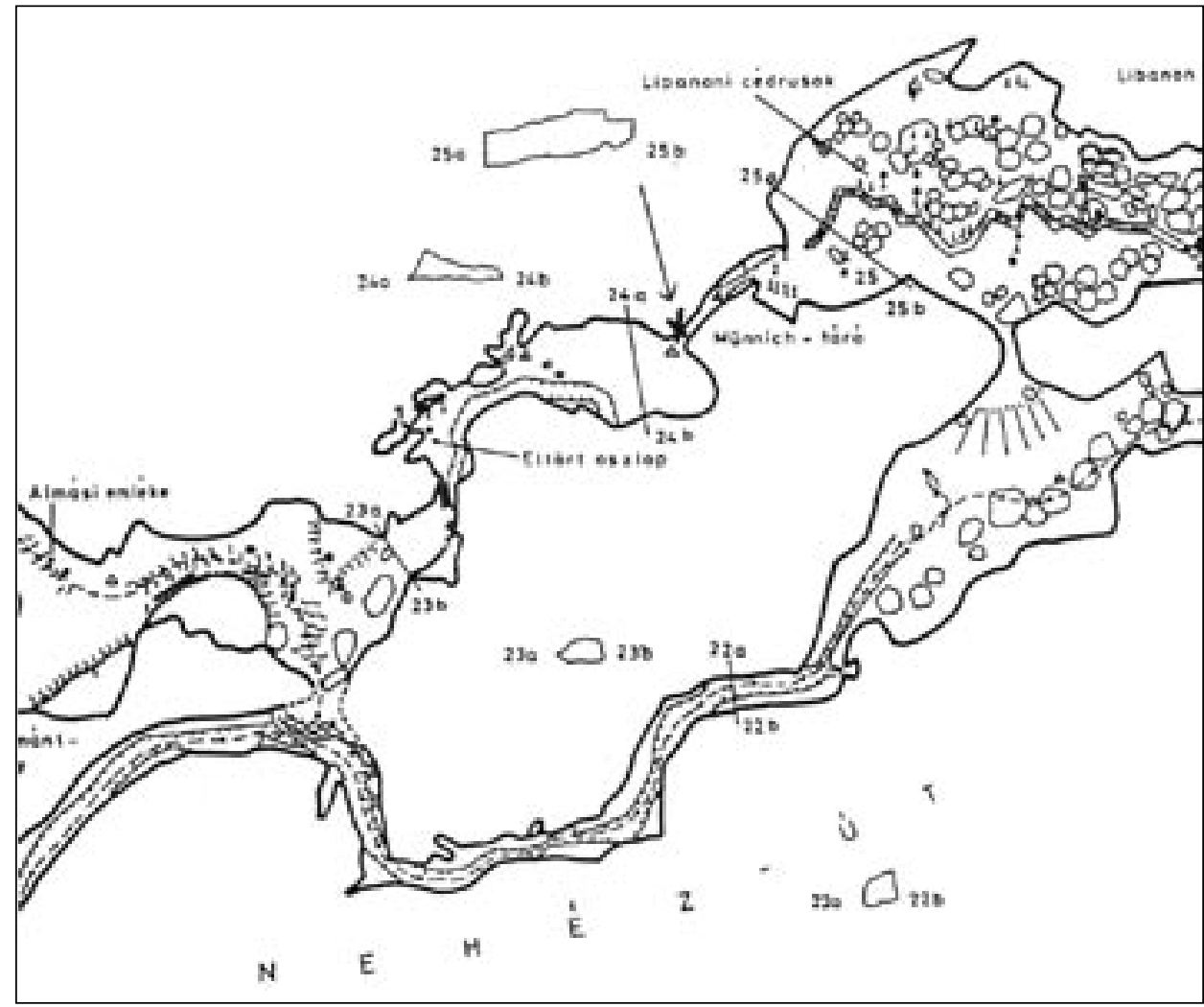

Fig. 12: Location of the BCE profile (Münnich-táró), map sheet No. 5. of the Baradla-Barlang 1: 1000, 1989).

\begin{tabular}{|l|l|l|l|l|l|l|}
\hline Sample & Lab. No. & $\begin{array}{l}\text { U conc. } \\
\text { [ppm] }\end{array}$ & ${ }^{234} \mathrm{U} /{ }^{238} \mathrm{U}$ & ${ }^{230} \mathrm{Th} /{ }^{234} \mathrm{U}$ & ${ }^{230} \mathrm{Th} /{ }^{232} \mathrm{Th}$ & $\begin{array}{l}\text { Age } \\
{[\mathrm{ka}]}\end{array}$ \\
\hline BCE 4/2 & W 807 & $0.276 \pm 0.008$ & $1.220 \pm 0.040$ & $0.652 \pm 0.023$ & 122 & $\begin{array}{c}114^{+7.3} \\
-6.9\end{array}$ \\
\hline BCE 4/1 & W 808 & $0.244 \pm 0.007$ & $1.312 \pm 0.045$ & $0.655 \pm 0.023$ & 60 & $115^{+7.6}$ \\
\hline
\end{tabular}

Table 4: $U$-series dating results using $\alpha$-spectrometry.

The quoted errors are one standard deviation. 
U-series dating of lower part of reverse polarised part of speleothem in Münnich-táró (BCE) indicated the average age of 114-115 ka (Tab. 4). Reverse polarisation can be correlated with the Blake Event, which was dated in Chinese loesses by Zhu et al. (1994) from $117.1 \pm 1.2$ to $111.8 \pm 1 \mathrm{ka}$.

\section{Mineralogical analysis}

General results can be stated from X-day diffraction study of 7 cave sediments and 3 surface clay samples: (1) illite and feldspar is always present in cave sediments; (2) illite occurs usually (or only) in cave sediments, while kaolinite is usually present in surface samples; (3) kaolinite is inversely proportional to the quantity of quartz, and (4) calcite and haematite are missing in cave samples and they are rare also in surface samples. X-ray analyses were carried out in the Mineralogical Department, ELTE-TTK, Budapest, Hungary (analyst: Gy. Lovas).

\section{DISCUSSION}

Obtained data from various sites within the Domica-Baradla Cave System indicate that both sediments and flowstones are younger than $780 \mathrm{ka}$ (Brunhes/Matuyama boundary). No data older than about 130 to $150 \mathrm{ka}$ were obtained from numerical dating of speleothems (cf. Pruner et al., 2000; L. Zámbó and D.C. Ford, pers. com. 2003). Also present data from Baradla Cave fit well into the general picture whether obtained in the main passage or in the upper cave level.

Sediments in all studies profiles within the Baradla Cave had nearly uniform composition (silts to clays, with rare sand/gravel intercalations) and textures indicating low energetic environment of deposition (stagnant waters to slow flow). Deposition was periodically or randomly interrupted, which resulted in formation of flowstone crusts and interbeds. They differ from sediments in the Domica Cave (Pruner et al., 2000), which are more reddish or brownish red derived from karst soils and transported to the cave from main ponors on carbonate rocks. Sediments from Baradla Cave contain the higher proportion of material derived from weathered matrix of the Poltár Formation transported to the cave by waters as the load through the invasion vadose passages (e.g., Törokmecset-ág, Retekág, Arany-utca), i.e. from ponors of allogenic streams.

The similarity of deposits both in the main corridor of Baradla Cave and in the upper cave level, as well as palaeomagnetic results, can indicate one-phase depositional event responsible deposition of studied sediments. This fact can indicate that the cave was filled with fine-grained siliciclastics when outflow routes (karst springs) were completely closed (collapse, filling by ice, etc.). Palaeomagnetic and U-series data from the upper cave level (Münnich-táró) dates this event before the last interglacial age (Eehmian), as the Blake Event was discovered in the flowstone/stalagmite covering the sedimentary profile and U-series dating of stalagmites by Lauritzen \& Leél-Őssy (1994), and L. Zámbó and D.C. Ford (pers. com., 2003) indicated also ages from 75 to about $150 \mathrm{ka}$ (see also Fig. 1).

Recent situation shows that fine siliciclastics, which filled the cave before ca 75-150 ka even at high altitudes, have been slowly removed from the cave, probably as a consequence of post-glacial cave evolution and/or valley entrenchment (lowering of karst spring positions). It cannot be excluded that a similar situation, i.e. complete fill of the cave system by fine-grained siliciclastics and their nearly complete exhumation occurred several times in the geological history due to the blockage of drainage routes due to geological (collapse) or palaeoclimatic (ice) reasons. Clear and distinct 
P. Bosák \& H. Hercman \& J. Kadlec \& J. Móga \& P. Pruner: Palaeomagnetic and U-series dating of cave sediments...

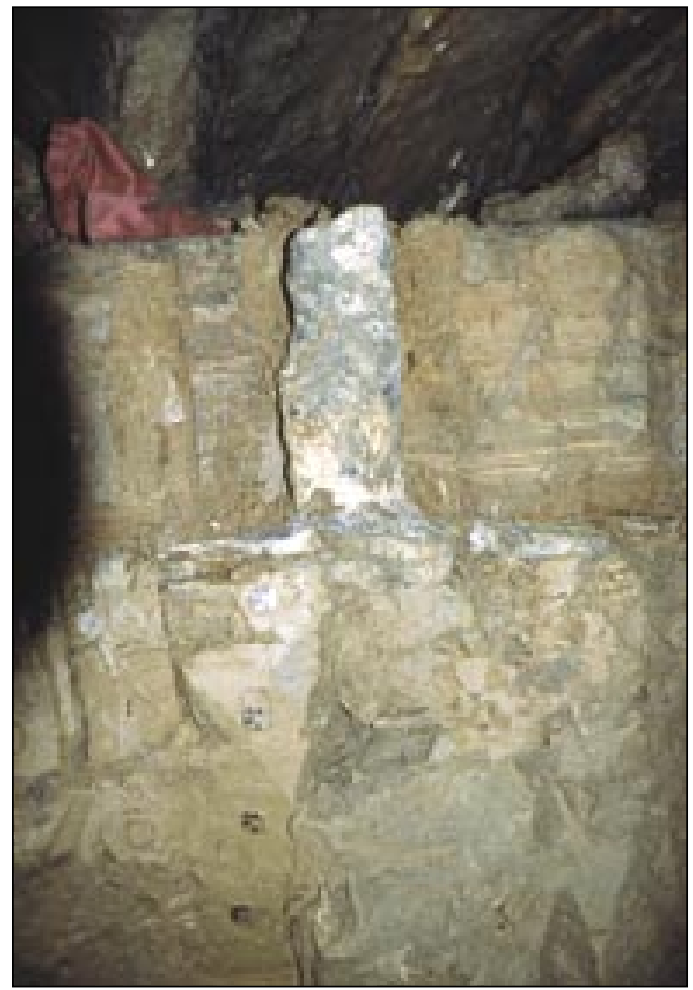

Fig. 13: Laminated layers and dripstone column embedded, Münnich-tunnel (BCE).

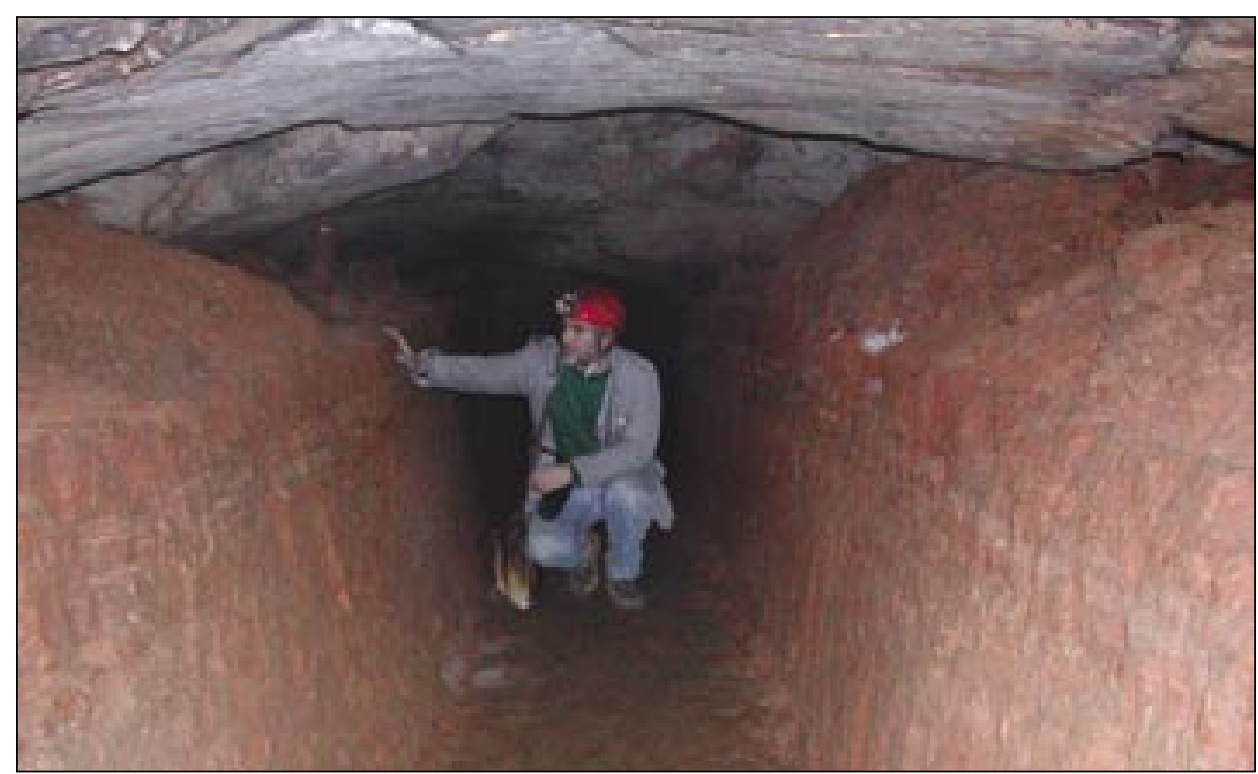

Fig. 14: Münnich-tunnel, artificial trench on the upper level of the cave (BCE). 
paragenetic features both in Domica part and in Baradla continuation seem to support the hypothesis. There are another indications of such polyphase development, such as eroded relics of cemented gravels resembling the Poltár Formation near the cave roof in the Domica Cave, eroded remains of coloured speleothems on walls in the Domica Cave, missing older sediments and speleothems in the whole system.

\section{CONCLUSIONS}

Five sedimentary profiles in the Baradla part of the Domica-Baradla Cave System were analysed for their palaeomagnetic properties. This study was completed by X-ray diffraction studies and Useries dating of flowstone/spelothems. Profiles were situated at the main cave level (principal cave corridor) and in the upper cave level, as well as in some of side passages (invasion vadose passages). Sedimentary deposits up to $2 \mathrm{~m}$ in thickness were lithologically highly uniform (unconsolidated fine-grained siliciclastics - clays to silts, some sandy intercalations, lamination and local cross-lamination). Flowstones formed caps of profiles and /or intercalations in siliciclastics. Alternating filed demagnetisation (unconsolidated sediments) and thermal demagnetisation (flowstone/stalagmite) indicated normal magnetic polarisation of all samples, i.e. the age younger than Brunhes/Matuyama boundary at $780 \mathrm{ka}$. Flowstone/stalagmite covering siliciclastics in the upper cave level contains reverse polarised samples dated by U-series method to about 114-115 ka, which can be identified as

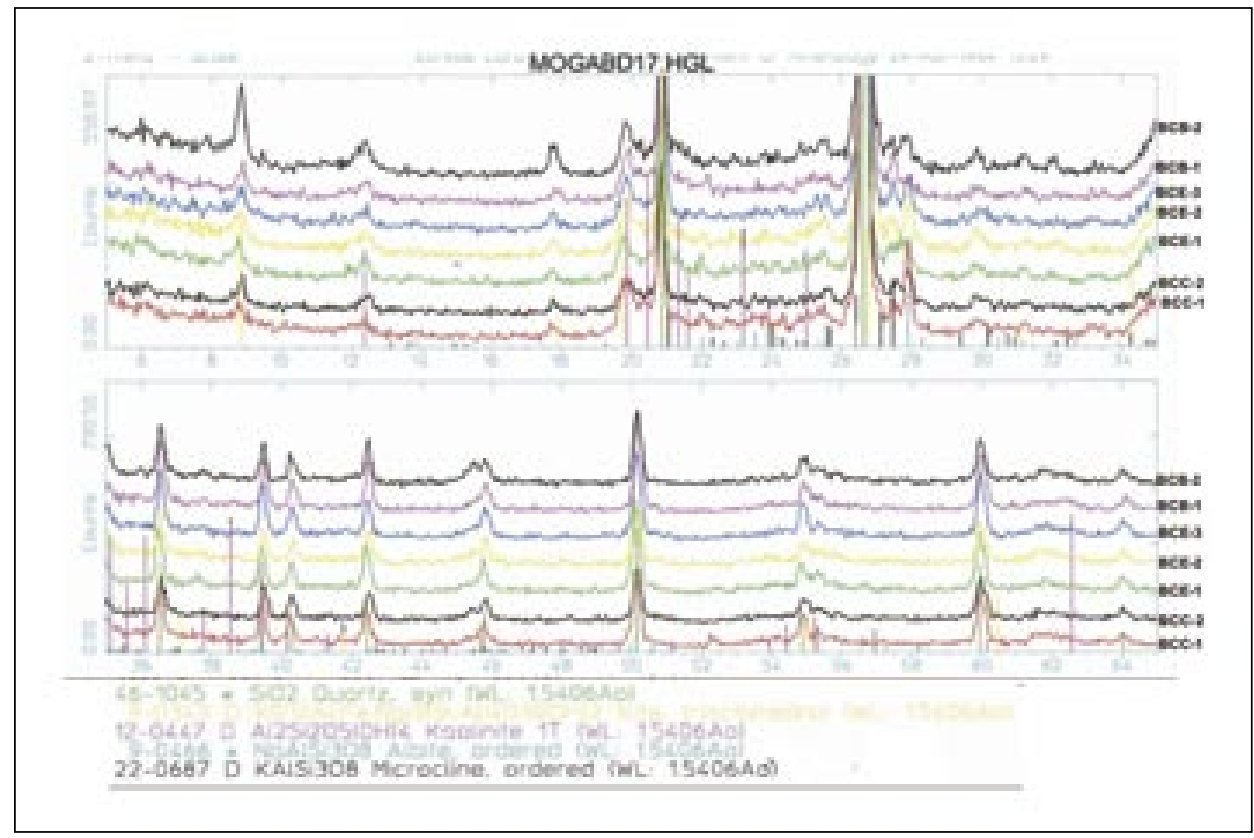

Fig. 15: The X-Ray diagram of the sediments of Baradla cave

Legend: The colours of the diagram reflect partly the samples of the 3 profiles $(B C B, B C C, B C E)$, on the other hand the phases of minerals. The values are relative, not numerical. 
the Blake Event. The uniform composition of sediments can indicate the infill of the cave during a single event caused by the blockage of drainage routes due to geological (collapse) or palaeoclimatic (ice) changes, which took part before ca 130 to $150 \mathrm{ka}$ as indicating by the oldest U-series data from the whole Domica-Baradla Cave System.

\section{ACKNOWLEDGEMENTS}

The study was carried out in the frame of grant project of the Hungarian Scientific Research Fund (OTKA) No. T 035004 (The study of the Quarternary development of the Gömör-Torna Karst and the palaeomagnetic research of the sediments from the Baradla-cave; 2001-2002) and the Grant Agency of the Academy of Sciences CR No. IAA3013201 (Magnetomineralogical and magnetostratigraphic research of cave and fluvial sediments in the Central European region; 2002-2005). We are grateful to authorities of the Aggtelek National Park (Josvafö) for necessary permission and to Administration of Slovak Caves (Liptovský Mikuláš) for necessary permission, willing co-operation and help.

\section{REFERENCES}

Bella, P., 2000: Problematika vývojových úrovni jaskyne Domica. - Aragonit, 5, 3-6. Liptovský Mikuláš.

Fisher, R., 1953: Dispersion on a sphere. - Proc. Roy. Soc., A 217, 295-305. London.

Gorka, P. \& Hercman, H., 2002: URANOTHOR v. 2.5. Delphi Code of calculation program and user guide. - MS, Arch. Inst. Geol. Sci., PAS, Warsaw.

Ivanovich, M. \& Harmon R.S., Eds., 1992: Uranium Series Disequilibrium: Applications to Environmental Problems. - Clarendon Press, 571 pp. Oxford.

Jakucs, L., 1956: Adatok az Aggteleki-hegység és barlangjainak morfogenetikájához. - Földr. Közl., 80, 1, 25-39. Budapest.

Jelínek, V., 1966: A high sensitivity spinner magnetometer. - Stud. geoph. geod., 10, 58-78. Praha.

Jelínek, V., 1973: Precision A.C. bridge set for measuring magnetic susceptibility and its anisotropy. - Stud. geoph. geod., 17, 36-48. Praha.

Kirschvink, J. L., 1980: The least-squares line and plane and the analysis of palaeomagnetic data. - Geophys. J. Royal Astronom. Soc., 62, 699-718. Oxford.

Lauritzen, S.E. \& Leél-Ốssy Sz., 1994: Előzetes koradatok egyes baradlai cseppkövekről. Karszt és Barlang, 1994. évf. I-II. füzet, 3-8. Budapest.

Mello, J. et al., 1997: Regionálne geologické mapy Slovenska 1:50 000. Geologická mapa Slovenského krasu. Vysvetlivky. - Geol. služba SR, 1-256. Bratislava.

Móga J., 1999: Reconstruction of the development history of karstic water network on the southern part of the Gömör-Torna karst on the basis of ruined caves and landforms. - Acta Carsologica, 28/2, 9, 159-174. Ljubljana.

Plašienka, D. 1999: Tectochronology and paleotectonic model of te Jurassic-Cretaceous evolution of the Central Western Carpathians (in Slovak, Engl. Summ.). - Veda, 1-128. Bratislava.

Př́íhoda, K., Krs, M., Pešina, B. \& Bláha, J., 1989: MAVACS - a new system of creating a non- 
magnetic environment for palaeomagnetic studies. - Cuad. Geol. Ibérica, 12, 223-250. Madrid.

Pruner, P., Bosák, P., Kadlec, J., Venhodová, D. \& Bella, P., 2000: Palaeomagnetický výzkum sedimentárních výplní vybranýchjeskyní na Slovensku. - Výskum, ochrana a využívanie jaskýňn, zborník referátov z 2. vedeckej konferencie, 13-25. Liptovský Mikuláš.

Sásdi, L. 1990: Az Aggtelek-Rudabányai-hegység karsztjának földtani fejlődéstörténete. - Karszt és Barlang, 1, 3-8. Budapest.

Szunyogh, G., 2002: Baradla New Atlas. Sheet No. 4.9.31. - Hungarian Cave Research Institute, Budapest.

Zámbó, L., Ford, D. \& Telbisz, T., 2002: Baradla-Barlangi Cseppkőkoradatok A Késő-Negyedidőszaki Klímaingadozások Tükrében. - Földtani Közlöny, 132/Különszám, 231-238. Budapest.

Zhu, R.X., Zhou, L.P., Laj, C., Mazaud, A. \& Ding, Z.L., 1994: The Blake geomagnetic polarity episode recorded in Chinese loesses. - Geophys. Res. Lett., 21, 8, 697-700.

Baradla-barlang (Baradla cave) 1:1000. Magyarország Barlangtérképei, Vol. 7. - Magyar Karszt- és Barlangkutató Társulat, Kpvdsz Vörös Meteor Természetbarát Egyesület. Budapest, 1989. 